\title{
Teknologi Diesel Particulat Filter Sebagai Upaya Mengurangi Emisi Gas Buang Dan Kebisingan Mesin Diesel Kendaraan Niaga
}

\author{
Moch. Aziz Kurniawan*1, Aat Eska Fahmadi², Yogi Oktopianto ${ }^{3}$, Siti Shofiah ${ }^{4}$ \\ 1,4Program Studi Pengujian Kendaraan Bermotor, \\ Politeknik Keselamatan Transportasi Jalan, Tegal \\ 2,3Program Studi Manajemen Keselamatan Transportasi Jalan, \\ Politeknik Keselamatan Transportasi Jalan, Tegal \\ E-mail: *aziz@pktj.ac
}

Received 10-09-2021; Reviewed 21-09-2021; Accepted 23-09-2021

Journal Homepage: http://ktj.pktj.ac.id/index.php/ktj

DOI: $10.46447 / \mathrm{ktj} . v 8 \mathrm{i} 2.350$

\begin{abstract}
The use of diesel engines in commercial vehicles is still the main choice and the most widely used. The increasing number of commercial vehicles that use diesel engines can pollute the environment and cause noise. In order to reduce exhaust emissions and noise in diesel engines, a particulate filter diesel technology was created which is installed in commercial vehicle diesel engines. This study uses an experimental method. The test was carried out on a Mitsubishi 1300 commercial vehicle diesel engine type 4D56 4 cylinder with a cylinder capacity of 2477 cc. The diesel particulate filter technology uses a half honeycomb model made from galvalume plates, with variations in the addition of filters in the form of glass wool of 50 grams, 100 grams, 150 grams, 200 grams, and 250 grams. Testing the exhaust emissions of a diesel engine using a TEN Automotive Equipment Innova 2000 multigas analyzer with a smoketester. Sound noise testing using a sound level meter test tool LT Lutron SL-4001. The test results with the addition of diesel particulate filter technology can reduce exhaust emissions and sound noise. The use of diesel particulate filter technology can reduce exhaust emissions in the form of Particulate Matter (PM) most optimally at the addition of a 100 gram filter with a decrease of $45.9 \%$. The most optimal reduction in noise is the addition of a 50 gram filter with a decrease of $26.5 \%$.
\end{abstract}

Keywords: Diesel engine, diesel particulate filter, exhaust emissions, noise

\begin{abstract}
Abstrak
Penggunaan mesin diesel pada kendaraan niaga masih menjadi pilihan utama dan paling banyak digunakan. Peningkatan jumlah kendaraan niaga yang menggunakan mesin diesel dapat mencemari lingkungan dan menimbulkan kebisingan suara. Dalam rangka mengurangi emisi gas buang dan kebisingan suara pada mesin diesel dibuatkan teknologi diesel particulat filter yang dipasang pada mesin diesel kendaraan niaga. Penelitian ini menggunakan metode eksperimental. Pengujian dilakukan pada mesin diesel kendaraan niaga Mitsubishi L300 tipe 4D56 4 silinder dengan kapasitas silinder 2477 cc. Teknologi diesel particulat filter menggunakan model half honeycomb berbahan plat galvalum dilakukan variasi penambahan filter berupa glasswod sebesar 50 gram, 100 gram, 150 gram, $200 \mathrm{gram}$, dan $250 \mathrm{gram}$. Pengujian emisi gas buang mesin diesel menggunakan alat uji TEN Automotive Equipment Innova 2000 multigas analyzer dengan smoketester. Pengujian kebisingan suara mengguna-
\end{abstract}


kan alat uji sound level meter LT Lutron SL-4001. Hasil pengujian dengan penambahan teknologi diesel particulat filter dapat menurunkan emisi gas buang dan kebisingan suara. Penggunaan teknologi diesel particulat filter dapat menurunkan emisi gas buang berupa Particulat Matter (PM) paling optimal pada penambahan filter 100 gram dengan penurunan sebesar $45,9 \%$. Penurunan kebisingan suara paling optimal pada penambahan filter $50 \mathrm{gram}$ dengan penurunan sebesar $26,5 \%$.

Kata kunci: Mesin Diesel, diesel particulat filter, emisi gas buang, kebisingan suara

\section{PENDAHULUAN}

Penggunaan kendaraan bermotor semakin meningkat seiring bertambahnya jumlah penduduk dan kebutuhan manusia terhadap transportasi. Penggunaan mesin diesel pada kendaraan niaga masih menjadi pilihan utama dan paling banyak digunakan karena pemakaian dan harga bahan bakar mesin diesel yang lebih murah dibandingkan dengan mesin bensin. Peningkatan jumlah kendaraan niaga yang menggunakan mesin diesel telah menyebabkan persoalan serius dalam hal peningkatan pencemaran udara. Emisi gas buang mesin diesel paling besar dan berbahaya adalah emisi Particulat Matter (PM). PM merupakan polutan yang dihasilkan oleh emisi gas buang pada mesin diesel dan dapat menimbulkan masalah kesehatan manusia apabila terhirup. PM dapat mencapai sistem respirasi dan paru-paru sehingga fungsinya dapat terganggu (Haryanto et al., 2016) .PM merupakan senyawa berbentuk asap hitam tebal berukuran 100 mikron hingga kurang dari 0,01 mikron. Apabila terhirup manusia dapat menggangu fungsi, mengendap dan menimbulkan flek hitam pada paru-paru. Penggunaan mesin diesel juga menimbulkan kebisingan suara yang dapat mengurangi kenyamanan penumpang di dalam kendaraan mesin diesel. Sebagai upaya untuk mengurangi emisi dan kebisingan suara pada mesin diesel diperlukan teknologi diesel particulat filter.

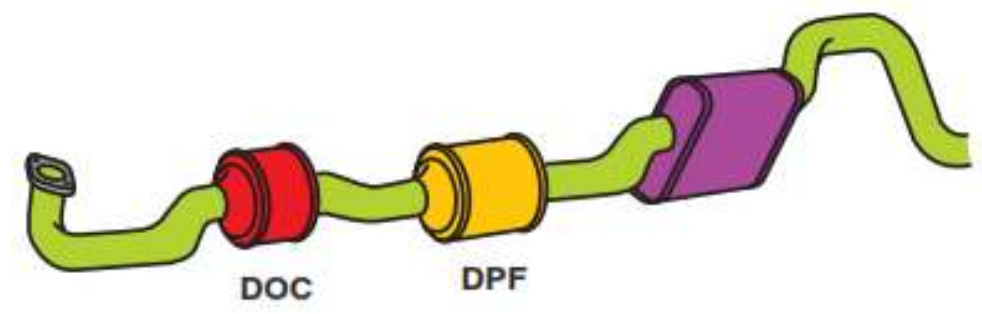

Gambar 1. Pemasangan Teknologi DPF

Teknologi diesel particulat filter (DPF) merupakan teknologi yang digunakan untuk menyaring emisi gas buang mesin diesel berupa PM yang dipasang di dekat saluran gas buang mesin diesel (Halderman. \& Linder, 2012). Penggunaan diesel particulat trap berbahan tembaga dan glasswol dengan model metallic honeycomb dapat mengurangi emisi mesin diesel sebesar 5,3 \% (Agung \& Muhaji, 2013). Penggunaan diesel particulat trap berbahan dasar stainless stee/dan glasswoo/dengan model metallic honeycomb (Ariyanto \& Warju, 2014). Dari hasil penelitian tersebut didapatkan hasil bahwasanya semakin kecil sisi kotak dapat menurunkan nilai emisi mesin diesel. Penurunan emisi yang paling baik pada ukuran $10 \mathrm{~mm}$ dengan penurunan emisi $75,5 \%$. 


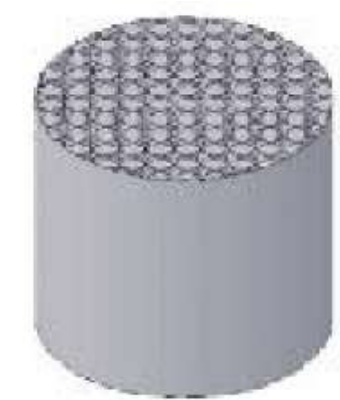

Gambar 2. Model diesel particulat trap Metallic Honeycomb

Diesel particulat filter disumulasikan laju aliran dengan koefesien gesek dan daya filtrasi partikel emisi gas buang melalui diesel particulat filter (Thiengkaew et al., 2015). Diesel particulat filter berbahan kuningan berukuran $260 \times 550 \mathrm{~mm}$ diteliti efisiensi dalam menyaring emisi gas buang mesin diesel. Penelitian tersebut menghasilkan penggunaan diesel particulat filter sangat efisien dalam menyaring emisi gas buang berupa PM hingga sebesar 95\% (Yu et al., 2017). Penggunaan diesel particulat filter dan katalis oksidasi diterapkan pada mesin dengan exhaust gas recirculation menggunakan bahan bakar campuran solar dan di ethyil ether. Dari hasil penelitian tersebut didapatkan hasil bahwasanya penggunaan diesel particulat filter dapat mengurangi emisi mesin diesel sebesar $75 \%$ (Banapurmath et al., 2018). Dari beberapa penelitian tersebut di atas penulis tertarik untuk menggunakan teknologi diesel particulat filter (DPF) pada mesin kendaraan niaga sebagai upaya mengurangi emisi gas buang dan kebisingan suara pada mesin diesel.

\section{METODE}

\section{Desain dan pembuatan Teknologi diesel particulat filter}

Teknologi diesel particulat filter didesain dengan model half honeycomb dengan bahan plat galvalume. Desain .menggunakan software Autodesk inventor 2016 student version. Perancangan dimulai dengan penggambaran komponen (part) dan dilanjutkan dengan penggabungan komponen (assembly part) seperti yang terlihat pada gambar 3. Ukuran Teknologi diesel particulat filter dibuat deangan spesifikasi panjang pipa 200 $\mathrm{cm}$; diameter dalam pipa $105 \mathrm{~cm}$ dan diameter dalam kerucut $55 \mathrm{~cm}$. Pemasangan sarangan juga ditambahkan pada bagian keluaran DPF untuk menjaga agar filter tidak mudah terbawa tekanan gas buang. Wadah filter teknologi diesel particulat filter dapat dibongkar pasang sehingga dapat dilakukan penggantian filter. Hasil pembuatan Teknologi diesel particulat filter dapat dilihat pada gambar 4.

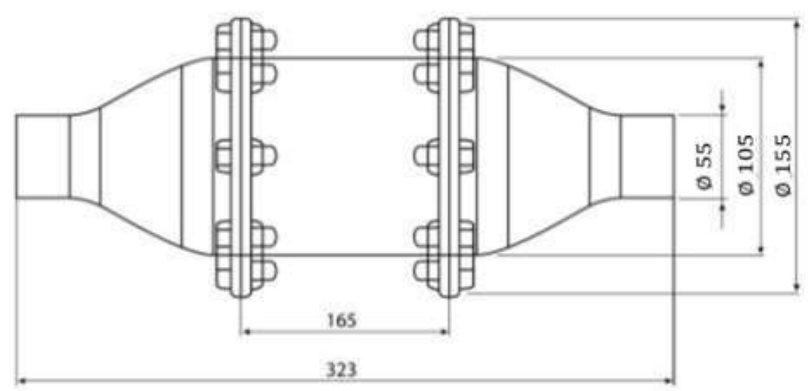

Gambar 3. Pembuatan desain dan ukuran teknologi diesel particulat filter 


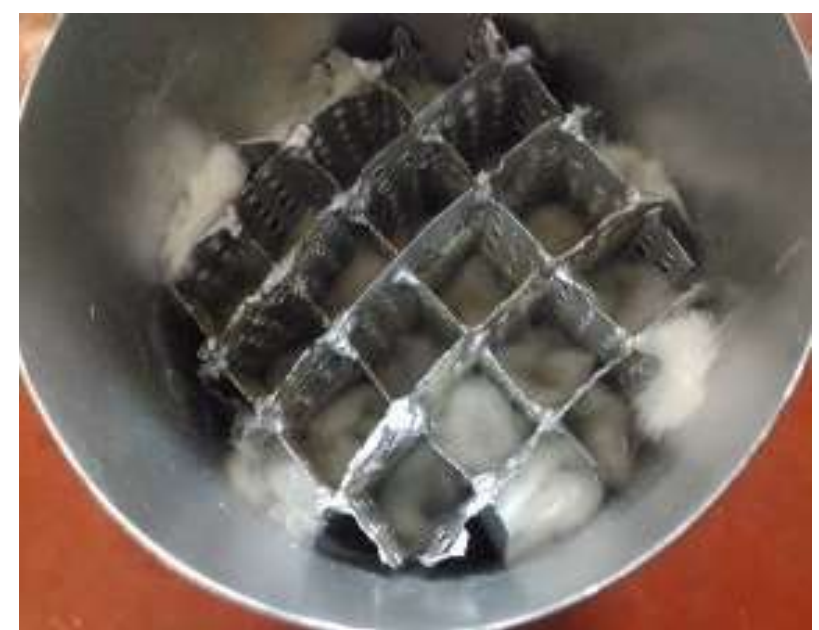

Gambar 4. Diesel Particulat Filter (DPF) dengan model half honeycomb

\section{Skema Rancangan Penelitian}

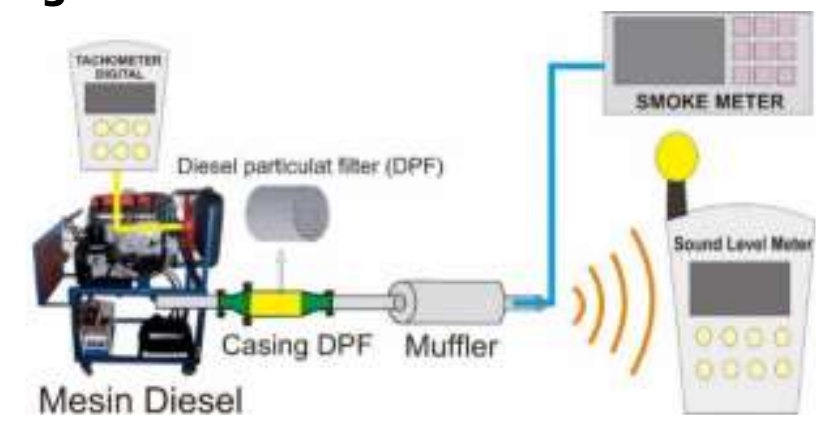

Gambar 5. Skema Pengambilan Data Penelitian

Pada penelitian ini pengambilan data dilakukan dengan cara eksperimen dengan skema pengambilan data pada gambar 5 . Mesin diesel yang digunakan adalah mesin diesel kendaraan niaga Mitsubishi L300 type 4D56. Eksperimen yang dilakukan adalah membandingkan emisi gas buang dan tingkat kebisingan mesin diesel dengan knalpot standard (tanpa pemasangan DPF) dan knalpot modifikasi (dengan pemasangan DPF) dengan variasi 50 gram, 100 gram, 150 gram, 200 gram, dan 250 gram.

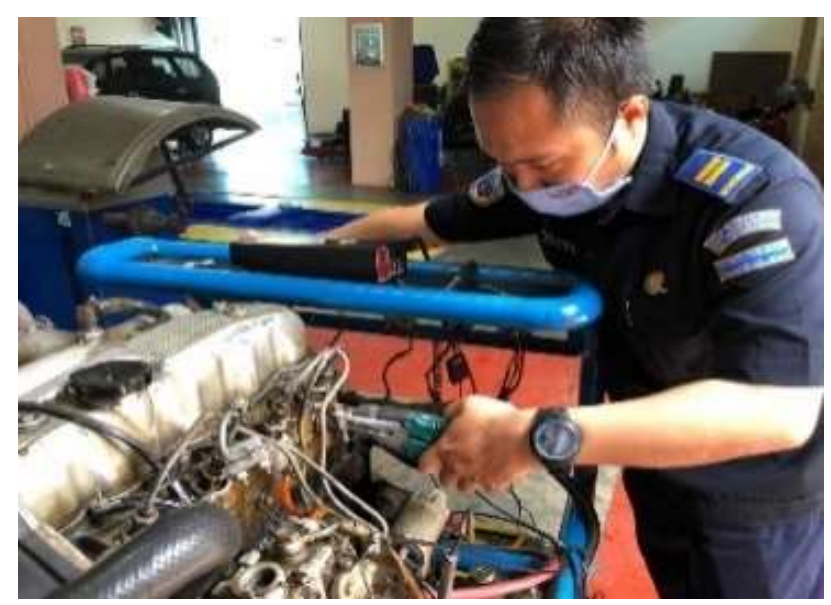

Gambar 6. Pemeriksaan dan tune up mesin diesel sebelum dilakukan pengujian

Sebelum dilakukan pengambilan data uji penelitian adalah memastikan mesin diesel kondisi dalam kondisi yang baik. Pengecekan dilakukan sesuai dengan buku 
manual mesin diesel tipe 4D56 (Mitsubishi Motors Coorporation. (1995) meliputi pemeriksaan tekanan kompresi nozle mesin diesel sebesar $120-130 \mathrm{~kg} / \mathrm{cm}^{2}$; pemeriksaan busi pijar dapat memanas hingga berwarna merah dengan suhu $300^{\circ}$ $500^{\circ} \mathrm{C}$; pengaturan celah katup intake 0,06 mm dan exhaust 0,09 $\mathrm{mm}$; penggantian oli mesin dan penggantian air pendingin mesin.

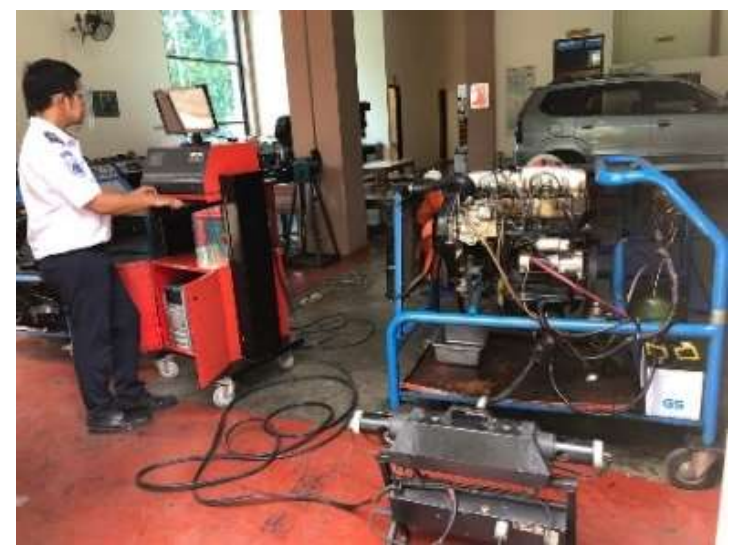

Gambar 7. Pengambilan data emisi tanpa teknologi diesel particulat filter

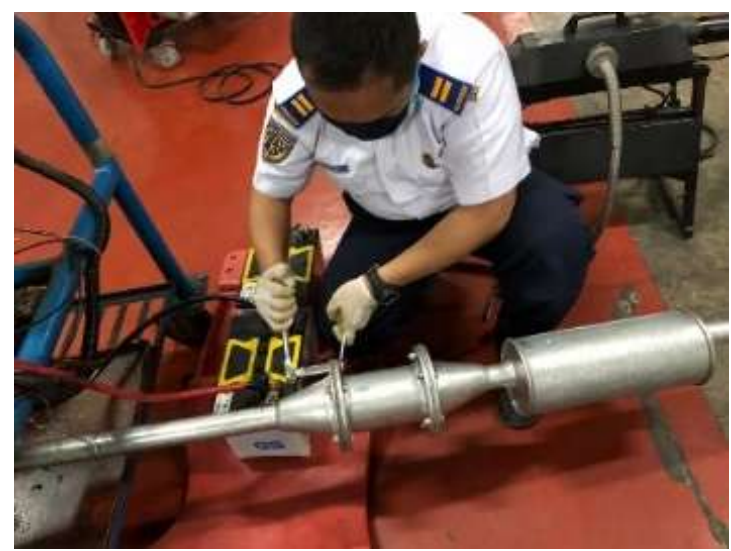

Gambar 8. Persiapan pemasangan teknologi diesel particulat filter

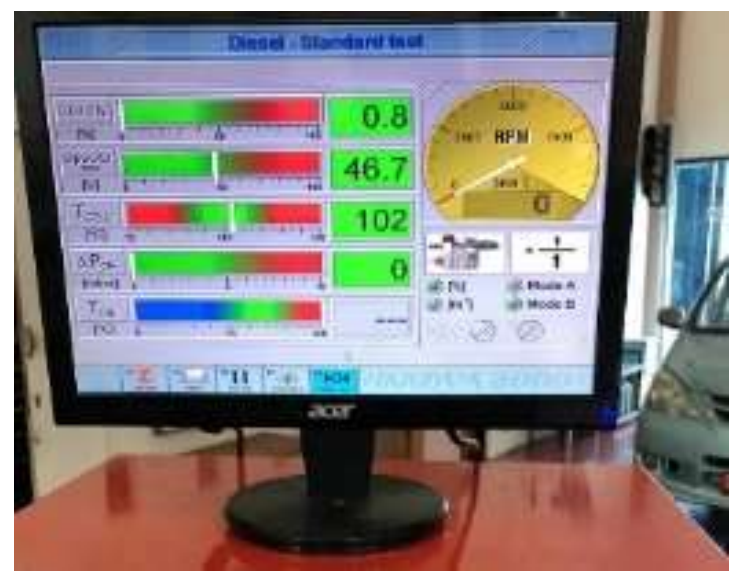

Gambar 9. Pengambilan data emisi dengan teknologi diesel particulat filter

Pengambilan data emisi gas buang dilakukan berdasarkan standar pengukuran emisi gas buang SAE-J1667 (snap acceleration test procedure) menggunakan alat uji TEN Automotive Equipment Innova 2000 multigas analyzer dengan smoketester 
seperti pada gambar 7 dan gambar 8 dengan prosedur sebagai berikut :

1. Menempatkan mesin diesel di tempat yang datar.

2. Menyalakan Mesin diesel hingga temperature oli mesin pada suhu kerja $\left(>80^{\circ} \mathrm{C}\right)$.

3. Menyiapkan alat uji pengukuran emisi gas buang mesin diesel TEN Automotive Equipment Innova 2000 multigas analyzer dengan smoketester.

4. Menunggu proses pemanasan alat uji (heating) sekitar 5 menit

5. Melakukan kalibrasi alat uji emisi gas buang

6. Memasukkan probe alat uji emisi mesin diesel sedalam $30 \mathrm{~cm}$

7. Melepas tuas gas dan menunggu hingga putaran idle stasioner

8. Mencatat hasil pengukuran uji emisi mesin diesel dalam satuan prosentase (\%) gas buang Particulat matter (PM).

9. Pengujian dilakukan sebanyak tiga (3) kali.

10. Memotong dan memasukkan filter ke dalam komponen diesel particulat filter dengan variasi 50 gram, 100 gram, 150 gram, 200 gram, dan 250 gram.

11. Memasang komponen diesel particulat filter ke dalam sistem knalpot

12. Melakukan pengujian emisi dengan mengulangi langkah 1 s/d langkah 9.

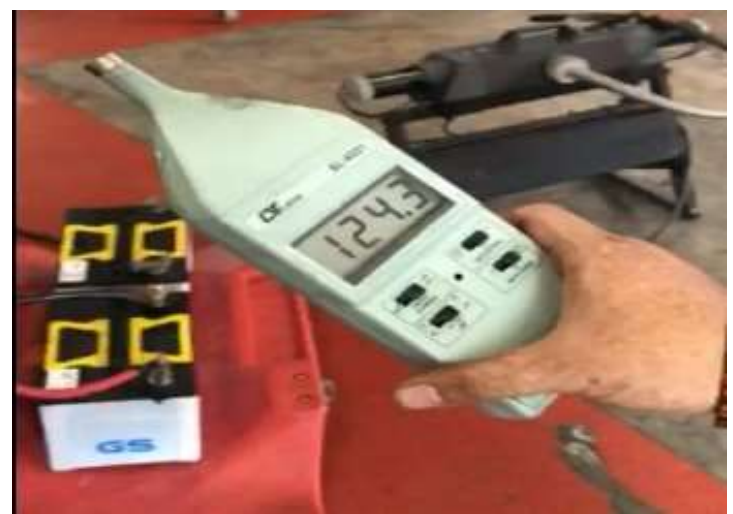

Gambar 10. Pengambilan data kebisingan suara tanpa teknologi diesel particulat filter

Pengambilan data kebisingan suara menggunakan alat sound level meter LTLutron SL-4001.buang dilakukan berdasarkan standar pengukuran emisi gas buang SAE-J1667 (snap acceleration test procedure). seperti pada gambar 9 dan gambar 10 dengan prosedur sebagai berikut :

1. Menyiapkan alat ukur sound level meter LT Lutron SL-4001

2. Memasang alat ukur kebisingan pada jarak 0,5 meter dari titik sumbu pipa knalpot dengan membentuk sudut 450 dan tinggi alat ukur kebisingan tidak kurang dari 0,2 meter dari tanah.

3. Menarik tuas gas maksimum secepatnya hingga mencapai putaran mesin maksimum, selanjutnya tahan hingga 3-5 detik.

4. Mencatat hasil uji kebisingan mesin diesel

5. Pengujian diulang sebanyak 3 kali percobaan

6. Memotong dan memasukkan filter ke dalam komponen diesel particulat filter dengan variasi 50 gram, 100 gram, 150 gram, 200 gram, dan 250 gram.

7. Memasang komponen diesel particulat filter ke dalam sistem knalpot

8. Melakukan pengujian kebisingan suara dengan Langkah $1 \mathrm{~s} / \mathrm{d}$ langkah 5 .

\section{Pengolahan Data Penelitian}

Teknik analisis data menggunakan metode deskriptif, yaitu dengan 
mendeskripsikan atau menggambarkan secara sistematis, faktual, dan akurat mengenai fakta yang diperoleh setelah melakukan pengujian (Nazir, 2005). Data hasil penelitian yang diperoleh dimasukkan dalam Tabel dan ditampilkan dalam bentuk diagram scatter untuk hasil uji emisi gas buang dan hasil uji kebisingan suara.

Langkah selanjutnya dideskripsikan dengan kalimat sederhana sehingga mudah dipahami sebagai upaya mendapatkan jawaban dari permasalahan yang diteliti. Hal ini dilaksanakan untuk memberikan fenomena yang terjadi antara sebelum pemasangan teknologi diesel particulat filter dan setelah dilakukan penambahan teknologi diesel particulate filter dengan variasi 50 gram, 100 gram, 150 gram, 200 gram, dan 250 gram terhadap hasil uji uji emisi gas buang dan hasil uji kebisingan suara.

\section{HASIL DAN PEMBAHASAN}

\section{Pengujian Emisi Gas Buang Mesin Diesel}

Tabel 1. Hasil Uji Emisi Gas Buang Mesin Diesel

\begin{tabular}{cccccc}
\hline $\begin{array}{c}\text { Kondisi } \\
\text { Penelitian }\end{array}$ & $\begin{array}{c}\text { Penambahan } \\
\text { filter (g) }\end{array}$ & $\begin{array}{c}\text { Pengambilan } \\
\text { ke-1 (\%) }\end{array}$ & $\begin{array}{c}\text { Pengambilan } \\
\text { ke-2 (\%) }\end{array}$ & $\begin{array}{c}\text { Pengambilan } \\
\text { ke-3 (\%) }\end{array}$ & $\begin{array}{c}\text { Rata- } \\
\text { Rata } \\
\text { (\%) }\end{array}$ \\
\hline $\begin{array}{c}\text { Tanpa Teknologi } \\
\text { Diesel Particulat } \\
\text { filter }\end{array}$ & 0 & 91,7 & 90,8 & 91,3 & 91,3 \\
\hline & & & & & \\
\hline Dengan & 50 & 78,8 & 78,3 & 78,1 & 78,4 \\
Teknologi Diesel & 100 & 56,6 & 55,7 & 55,3 & 55,9 \\
Particulat filter & 200 & 49,3 & 49,7 & 49,1 & 49,4 \\
& 250 & 46,1 & 46,3 & 46,2 & 46,2 \\
& 45,7 & 45,5 & 45,9 & 45,7 \\
\hline
\end{tabular}

Hasil penelitian tentang pengaruh pemasangan diesel particulat filter terhadap emisi gas buang mesin diesel dapat dilihat di dalam tabel 1. Pada tabel 1 menunjukkan bahwa pemasangan teknologi diesel particulat filter (DPF) dapat menurunkan emisi gas buang mesin diesel. Penambahan filter sebesar 50 gram dapat menurunkan emisi gas buang sebesar $14,1 \%$. Penambahan filter sebesar 100 gram dapat menurunkan emisi sebesar 38,8\%. Penambahan filter sebesar 150 gram dapat menurunkan emisi sebesar 45,9\%. Penambahan filter sebesar 200 gram dapat menurunkan emisi sebesar 49,4\%. Penambahan filter sebesar 250 gram dapat menurunkan emisi PM sebesar 49,9\%. Penurunan emisi gas buang terjadi karena emisi partikulat mesin diesel terjebak di dalam filter teknologi DPF. Semakin banyak filter maka semakin banyak emisi partikulat yang terjebak.

Gambar 11 menunjukkan grafik hasil Pengujian emisi gas buang mesin diesel yang dilakukan pada knalpot standard (tanpa Teknologi DPF) dan knalpot dengan teknologi DPF yang divariasikan dengan penambahan filter 50 gram, 100 gram, 150 gram, 200 gram, dan 250 gram. Dari grafik tersebut menunjukkan bahwa penambahan 100 gram dapat menurunkan emisi PM mesin diesel paling optimal, yaitu sebesar 45,9 $\%$. Penambahan filter selanjutnya tetap menunjukkan penurunan emisi gas buang, namun hanya $4 \%$ dari penambahan 100 gram menjadi 250 gram. Hal ini terjadi karena pada penambahan filter 100 gram dapat menjebak partikulat pada seluruh area DPF. 
Grafik Pengaruh Penggunaan Diesel Partikulat Filter Terhadap Emisi PM

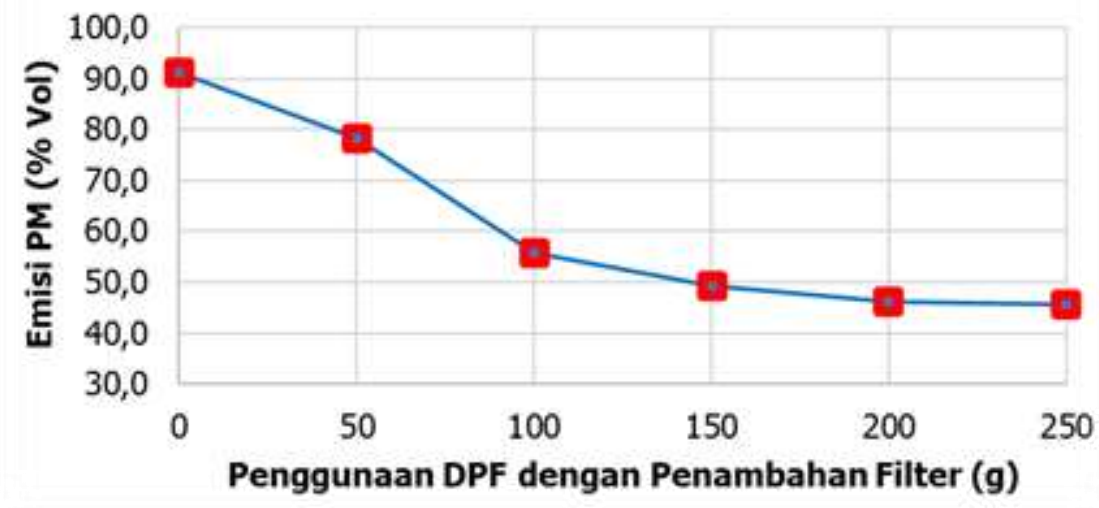

Gambar 11. Grafik Hasil uji emisi gas buang mesin diesel

\section{Pengujian Kebisingan Suara Mesin Diesel}

Tabel 2. Hasil uji kebisingan suara mesin diesel

\begin{tabular}{|c|c|c|c|c|c|}
\hline Kondisi Penelitian & $\begin{array}{l}\text { Penambahan } \\
\text { Filter (g) }\end{array}$ & $\begin{array}{l}\text { Pengambilan } \\
\text { ke-1 (dB) }\end{array}$ & $\begin{array}{l}\text { Pengambila } \\
\text { ke-2 (dB) }\end{array}$ & $\begin{array}{l}\text { InPengambilan } \\
\text { ke-3 (dB) }\end{array}$ & $\begin{array}{l}\text { Rata-rata } \\
\text { (dB) }\end{array}$ \\
\hline $\begin{array}{c}\text { Tanpa Teknologi Diesel } \\
\text { Particulat filter }\end{array}$ & 0 & 124,3 & 123,7 & 124,5 & 124,2 \\
\hline \multirow{5}{*}{$\begin{array}{l}\text { Dengan Teknologi } \\
\text { Diesel Particulat filter }\end{array}$} & 50 & 91,3 & 90,8 & 91,5 & 91,2 \\
\hline & 100 & 88,3 & 88,7 & 88,1 & 88,4 \\
\hline & 150 & 86,6 & 86,2 & 86,9 & 86,6 \\
\hline & 200 & 84,9 & 84,1 & 84,7 & 84,6 \\
\hline & 250 & 83,6 & 83,1 & 82,9 & 83,2 \\
\hline
\end{tabular}

Dari tabel 2 menunjukkan bahwa dengan pemasangan teknologi DPF dapat menurunkan kebisingan suara mesin diesel. Penambahan filter sebesar 50 gram dapat menurunkan kebisingan suara sebesar 26,5\%. Penambahan filter sebesar 100 gram dapat menurunkan kebisingan suara sebesar 28,8 \%. Penambahan filter sebesar 150 gram dapat menurunkan kebisingan suara sebesar 30,3\%. Penambahan filter sebesar 200 gram dapat menurunkan kebisingan suara sebesar 31,9\%. Penambahan filter sebesar 250 gram dapat menurunkan kebisingan suara PM sebesar 32,9\%. Penurunan kebisingan suara terjadi karena penambahan filter pada teknologi DPF dapat meredam suara kebisingan suara pada mesin diesel. Semakin banyak filter maka peredaman semakin baik dan menurunkan kebisingan suara.

Gambar 12 menunjukkan grafik hasil Pengujian kebisingan suara mesin diesel. Dari grafik tersebut menunjukkan bahwa penambahan 50 gram dapat mengurangi kebisingan suara mesin diesel paling optimal, yaitu sebesar $26,5 \%$. Penambahan filter selanjutnya tetap menunjukkan penurunan kebisingan suara, namun hanya $6 \%$ dari penambahan $100 \mathrm{gram}$ menjadi $250 \mathrm{gram}$. Hal ini terjadi karena penambahan filter 50 gram sudah dapat meredam suara area DPF pada mesin diesel sehingga kebisingan suara mesin diesel dapat berkurang. 


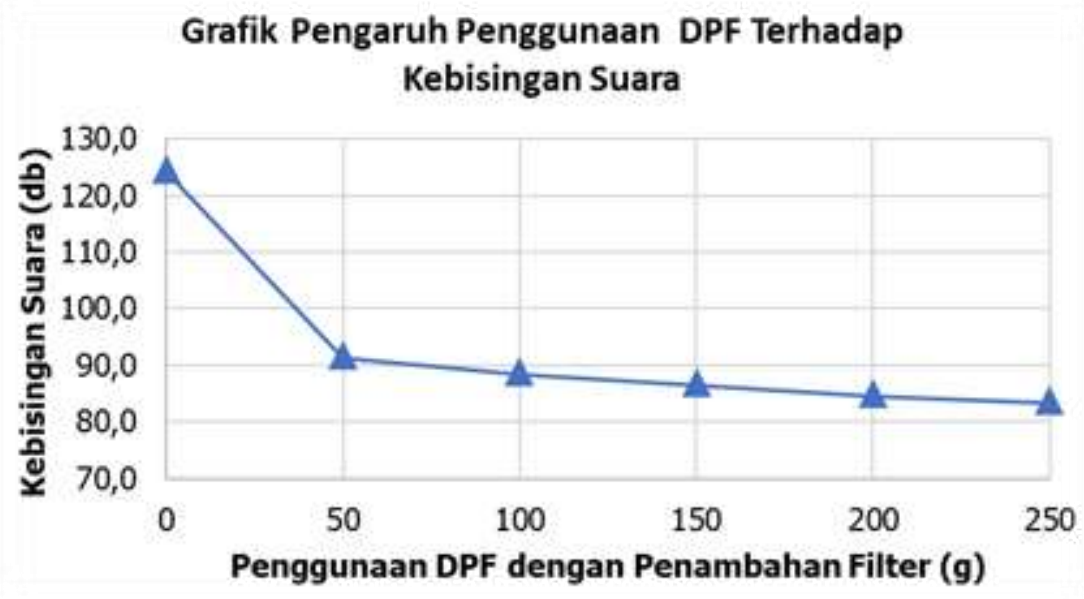

Gambar 12. Grafik Hasil uji kebisingan suara mesin diesel

\section{SIMPULAN}

Pemasangan teknologi Diesel Particulat Filter (DPF) pada mesin diesel kendaraan niaga Mitsubishi L300 tipe 4D56 dapat menurunkan emisi gas buang mesin diesel. Semakin banyak penambahan filter maka semakin menurunkan emisi gas buang mesin diesel. Penambahan filter yang paling optimal adalah penambahan filter sebesar 100 gram dapat menurunkan emisi PM mesin sebesar 45,9 \%. Penambahan filter selanjutnya tetap menunjukkan penurunan emisi gas buang, namun hanya $4 \%$ dari penambahan $100 \mathrm{gram}$ menjadi $250 \mathrm{gram}$. Hal ini terjadi karena pada penambahan filter 100 gram dapat menjebak partikulat pada seluruh area DPF.

Pemasangan teknologi DPF dapat menurunkan kebisingan suara pada mesin diesel. Penambahan filter pada DPF semakin menurunkan kebisingan suara pada mesin diesel. penambahan 50 gram dapat mengurangi kebisingan suara mesin diesel paling optimal, yaitu sebesar $26,5 \%$. Penambahan filter selanjutnya tetap menunjukkan penurunan kebisingan suara, namun hanya $6 \%$ dari penambahan 100 gram menjadi $250 \mathrm{gram}$. Hal ini terjadi karena pada penambahan filter $50 \mathrm{gram}$ bersifat meredam suara area DPF pada mesin diesel.

\section{DAFTAR PUSTAKA}

Agung, S., \& Muhaji. (2013). Pengaruh Penggunaan Diesel Particulate Trap Berbahan Tembaga dan Glasswool Terhadap Performa Mesin Isuzu Panther Tahun 2000. Jurnal Teknik Mesin, 02(01), 48-54.

Ariyanto, S. R., \& Warju. (2014). Rancang Bangun Diesel Particulate Trap (DPT) Untuk Mereduksi Opasitas, Konsumsi Bahan Bakar, dan Tingkat Kebisingan Mesin Isuzu C190. Jurnal Rekayasa Mesin (JRM), 01(03), 19-28. https://jurnalmahasiswa.unesa.ac.id/index.php/jurnal-rekayasamesin/article/view/8910/8907

Banapurmath, N. R., Nagaprasad, K. S., Madhu, D., \& Khandal, S. V. (2018). Effects of Using Diesel Particulate Filter and Diesel Oxidation Catalyst with Exhaust Gas Recirculation on the Performance of Compression Ignition Engine Fuelled with Diesel- Di Ethyl Ether Blend. European Journal of Sustainable Development Research, 2(3). https://doi.org/10.20897/ejosdr/87153

Halderman., J. D., \& Linder, J. (2012). Automotive Fuel and Emissions Control Systems. 
Pearson Education.

Haryanto, B., Resosoedarmo, B., Utami, S. T. B., Hartono, B., \& Hermawati, E. (2016). Effect of Ambient Particulate Matter 2.5 Micrometer (PM2.5) to Prevalence of Impaired Lung Function and Asthma in Tangerang and Makassar. Kesmas: $\begin{array}{llll}\text { National Public Health } 145 . & \end{array}$ https://doi.org/10.21109/kesmas.v10i4.823

Mitsubishi Motors Coorporation. (1995). Engine 4D56 manual book. Japan : Mitsubishi Motors Coorporation

Nazir, Moh. 2005. Metode Penelitian. Bogor: Penerbit Ghalia Indonesia.

SAE J1667. 1996-02. Snap Acceleration Smoke Test Procedure for Heavy-Duty Powered Vehicles.

Thiengkaew, K., Khongsup, V., \& Wirojsakunchai, E. (2015). Sensitivities of Diesel Particulate Filter clean and loading models. MATEC Web of Conferences, 34. https://doi.org/10.1051/matecconf/20153402005

Turns, S.R, An Introduction to combustion. 2000. United States : Mc Graw Hill

Yu, Q. S., Tan, J. W., Ge, Y. S., Hao, L. J., \& Peng, Z. H. (2017). Application of Diesel Particulate Filter on in-use On-road Vehicles. Energy Procedia, 105, 1730-1736. https://doi.org/10.1016/j.egypro.2017.03.496 